\title{
Biochemical and genetic alterations in the freshwater neotropical fish Prochilodus lineatus after acute exposure to Microcystis aeruginosa
}

\author{
Cylene Zambrozi Garcia and Claudia B. R. Martinez
}

Microcystins are secondary metabolites produced by different species of cyanobacteria, such as Microcystis aeruginosa (MA). In this study, the biochemical and genetic effects of lyophilized MA were evaluated in the neotropical fish Prochilodus lineatus exposed to 1 or $2 \mathrm{mg} \mathrm{L}^{-1}$ lyophilized MA (treated group) or only water (control group) in static toxicity tests for 24 and $96 \mathrm{~h}$. The gills and liver were used in the analysis of biotransformation enzymes and antioxidant defenses, blood and gill cells in genetic analysis and in brain and muscle it was determined the activity of acetylcholinesterase (AChE). The results showed the biotransformation pathway activation due to the increase in hepatic CYP1A and in branchial and hepatic glutathione Stransferase (GST). The antioxidant defense proved to be greatly affected by MA exposure leading to changes, both in gills and liver, in the activities of superoxide dismutase (SOD), catalase (CAT), glutathione peroxidase (GPx), glutathione reductase (GR) and in the content of tripeptide glutathione (GSH). Lipid peroxidation was not detected, but damage to DNA molecule was observed in blood cells. In conclusion, it can be state the lyophilized MA is able to promote changes in the biochemical and genetic parameters of $P$. lineatus.

As microcistinas são metabólitos secundários produzidos por diferentes espécies de cianobactérias, como a Microcystis aeruginosa (MA). Neste estudo, os efeitos bioquímicos e genéticos de liofilizado de MA foram avaliados para juvenis da espécie de peixe Neotropical Prochilodus lineatus expostos a 1 ou $2 \mathrm{mg} \mathrm{L}^{-1}$ de liofilizado de MA (grupo tratado) ou apenas à água (grupo controle), em testes de toxicidade estáticos, durante 24 e $96 \mathrm{~h}$. As brânquias e o fígado foram usados para as análises das enzimas de biotransformação e defesas antioxidantes, células do sangue e das brânquias para análises genéticas e no cérebro e músculo foi determinada a atividade da acetilcolinesterase (AChE). Os resultados mostraram ativação da via de biotransformação devido ao aumento da atividade da CYP1A hepática e da atividade da glutationa S-transferase (GST) hepática e branquial. As defesas antioxidantes foram muito afetadas pela exposição a MA levando a alterações, tanto no fígado como nas brânquias, na atividade da superóxido dismutase (SOD), da catalase (CAT), da glutationa peroxidase (GPx), glutationa redutase (GR) e no conteúdo do tripeptídeo glutationa (GSH). Apesar dessas alterações a peroxidação lipídica não foi detectada em nenhum dos tecidos, mas danos na molécula de DNA foram observados nas células do sangue. Em conclusão, pode-se afirmar que o liofilizado de MA é capaz de promover alterações em parâmetros bioquímicos e genéticos de $P$. lineatus.

Key words: Acetylcholinesterase, Antioxidants, Biotransformation, Cyanotoxin, DNA damage.

\section{Introduction}

Microcystins (MC) are cyanotoxins which occur in freshwaters worldwide and are produced by different genera of cyanobacteria such as Anabaena, Nostoc, Planktothrix and mainly Microcystis (Atencio et al., 2008). MCs are cyclic peptides with seven amino acids connected via peptide bonds in a cyclic conguration. The different variants of MCs are formed mainly because of variations of the $\alpha$-amino acids found at positions 2 and 4; for example in MC-LR, LR stands for leucine (L) and arginine (R) (Antoniou et al., 2008). Different combinations of L-amino acids can be found in different types of $\mathrm{MC}$ and so far more than 80 isoforms have been identified, among which the MC-LR stands out as being the most toxic and frequent. About its characteristics, the $\mathrm{MC}$ has a molecular weight ranging from $800-1000$ Daltons; is soluble in water and unable to cross the lipid membrane of animals, plants and bacteria and is resistant to temperature, chemical hydrolysis and oxidation (Amado \& Monserrat, 2010). MCs are known to affect many organisms, from microalgae to mammals (Atencio et al., 2008).

One of the most serious cases involving MC in Brazil occurred in a haemodialysis clinic in Pernambuco (BR), in 1996. Patients were exposed intravenously to water containing

Universidade Estadual de Londrina, Programa de Pós-Graduação em Ciências Biológicas e Departamento de Ciências Fisiológicas, Caixa Postal 6001, 86051-990 Londrina, PR, Brazil. cbueno@uel.br (CBRM) 
MC, causing the death of a large number of patients (Fischer et al., 2005; Chen et al., 2006). By being able to promote a range of adverse effects and, in some cases, cause death of individuals, the World Health Organization (WHO) established a maximum acceptable limit of MC-LR in drinking water as $1 \mu \mathrm{g} \mathrm{L}^{-1}$ and for foods from $0.04 \mu \mathrm{g} \mathrm{Kg}^{-1} \mathrm{day}^{-1}$ as Tolerance Daily Intake (TDI) of MC (WHO, 1998).

Fishes come in contact with this toxin by different routes, e.g., during feeding (Li et al., 2004) or passively through the gills during breathing (Zimba et al., 2001). Once inside the organism, the target organ of the $\mathrm{MC}$ is the liver and it may enter hepatocytes by two different routes: the bile acid receptor (Chen et al., 2006) or by Organic Anion Transporting Polypeptide (OATPs) (Fischer et al., 2005). However, other organs such as the gastrointestinal tract, kidney and brain also exhibit these transporters (Pasková et al., 2008), thus increasing the number of targets for this toxin. At the molecular level, the main targets of MCs are protein phosphatases (PP) of the serine/ threonine family. Inhibition of PPs promotes increased phosphorylation of proteins, resulting in the disruption of the microfilament cytoskeleton and loss of cell shape causing the destruction of the liver cell, which may lead to intrahepatic heamorrhage or liver failure (Campos \& Vasconcelos, 2010).

Some studies also attribute to MC's the ability of generate oxidative stress (Jos et al., 2005), increasing the generation of reactive oxygen species (ROS) (Li et al., 2003; Weng et al., 2007) and oxidative damage, such as lipid peroxidation (LPO) (Pinho et al., 2005) and damage to the DNA molecule (Zegura et al., 2003). The ROS are counteracted by the antioxidant defense system, which in aquatic organisms is represented mainly by antioxidant enzymes: superoxide dismutase (SOD), catalase (CAT), glutathione peroxidase (GPx) and glutathione reductase (GR), and non-enzymatic antioxidants as reduced glutathione (GSH) (Livingstone, 2001). When the antioxidant defense is not enough to combat the ROS, or they are in a large quantity, they can trigger oxidative damage in the form of damage to membrane lipids and DNA.

In addition to these oxidative stress biomarkers, assessment of the activity of the enzyme acetylcholinesterase (AChE) is also considered a very valuable tool (Ferrari et al., 2007). When the activity of this enzyme is reduced, acetylcholine remains accumulated in the synapses, altering the normal functioning of the nervous system and affecting the locomotion and equilibrium of fish (Dutta and Arends, 2003).

Changes in biochemical and genetic parameters of different fish species exposed to MC have been described in the literature. Cazenave et al. (2006) found, in liver and gills, significant changes in the detoxification enzyme glutathione S-transferase (GST), in antioxidant enzymes (GPx, GR and CAT) and also in LPO after exposure of Corydoras paleatus to different concentrations of MC-LR. Jos et al. (2005) observed induction of antioxidant defense and increase of LPO after exposure of tilapia (Oreochromis sp.) to cyanobacterial cells containing the MC, and the liver was the organ most affected, followed by kidney and gill. Zegura et al. (2003) proved, through the exposure of human HepG2 hepatoma cells of MC-LR, that this cyanotoxin is capable of promoting oxidative DNA damage. However, results concerning the effects of MC, more specifically the type LR (MC-LR), in freshwater fishes from the Neotropical region are still scarce. Thus, this study aimed to assess biochemical and genetic parameters of the neotropical fish species Prochilodus lineatus (common name: curimba) after exposure to lyophilized MA containing MC-LR.

\section{Material and Methods}

\section{Animals}

Juveniles of Prochilodus lineatus weighing $16.42 \pm 0.78 \mathrm{~g}$ $(\mathrm{n}=84)$, provided by the Fish Hatchery Station of Universidade Estadual de Londrina, were acclimated for one week in $300 \mathrm{~L}$ tanks containing dechlorinated and aerated water, and a light:dark cycle of 12:12 h. Physical and chemical parameters of the water were measured daily using a multiparameter water quality monitor (Horiba U-50) and remained constant (temperature: $21.08^{\circ} \mathrm{C}, \mathrm{pH}: 6.92$, conductivity: $110.80 \mu \mathrm{S} \mathrm{cm}^{-1}$ and dissolved oxygen: $8.52 \mathrm{mgO}_{2} \mathrm{~L}^{-1}$. During the period of acclimation, the animals were fed every two days with commercial pellet food containing $36 \%$ of crude protein (Guabi ${ }^{\circledR}, \mathrm{BR}$ ). Feeding was suspended $24 \mathrm{~h}$ before the start of toxicity tests and fish were not fed during the exposure periods. These procedures followed the standard protocols approved by the Committee for Animal Experimentation of Universidade Estadual de Londrina.

\section{Protocol for quantification of microcystin type LR}

Portions of lyophilized Microcystis aeruginosa (MA), strain NPLJ-4, were macerated, weighed and solutions were prepared with distilled water to be diluted in the aquarium where the fish were exposed. Before exposure, the solutions were frozen and thawing three times, to break cells for the release of cyanotoxins. After exposure, aliquots of water were collected for quantification of microcystin type LR (MC-LR) by immunoenzymatic assay on a microplate reader, using a commercial kit (Beacon), specific for MC-LR.

\section{Experimental procedures}

The fish were distributed in glass aquaria of $100 \mathrm{~L}$ (eight fish for aquarium) containing continuously aerated and dechlorinated water. The animals were exposed to different concentrations of lyophilized MA ( 1 or $2 \mathrm{mg} \mathrm{L}^{-1}$; treated animals) or only water (control animals) for 24 and $96 \mathrm{~h}$, in independent experiments. The control groups and respective treated groups were sampled simultaneously and all experiments were performed in duplicate. The following water parameters were monitored during the experiments: temperature, $\mathrm{pH}$, conductivity, and dissolved oxygen.

Immediately after being removed from the aquaria, fish were anaesthetized in benzocaine $5 \%$, for a maximum of $2 \mathrm{~min}$, for blood collection by caudal vein (Cavalcante et al., 2008). Blood samples were stored on ice for the comet assay. After the animals were weighed, measured and euthanized by medullar section 
to remove the gills, liver, brain and muscle, which were kept frozen at $-80^{\circ} \mathrm{C}$ until the biochemical assays (Simonato et al., 2011). Four gill arches were used for biochemical analysis and the other four were used for genetic analysis.

\section{Biochemical analyses}

The tissues (gills, liver, brain, and muscle) were weighed and homogenized (5x the volume for the gills and 10x the volume for the liver, brain, and muscle) in K phosphate buffer $(0.1 \mathrm{M})$ at $\mathrm{pH} 7.0$ for the gills and liver and $\mathrm{pH} 7.5$ for brain and muscle. The homogenates were then centrifuged (20 min, $13,200 \mathrm{~g}, 4^{\circ} \mathrm{C}$ ) and the supernatants were separated for enzymatic assays. Gills and liver were used for the determination of the activity of CYP1A, through the activity of etoxiresorufina-O-desetilase (EROD), GST, SOD, CAT, GPx and GR; the GSH content and the occurrence of lipid peroxidation (LPO). Brain and muscle were used for the determination of AChE activity.

The induction of CYP1A was determined by the analysis of EROD activity, estimated by the rate of conversion of 7ethoxyresorun to resorun, following the protocol outlined by Eggens et al. (1992), with modifications. The reaction was initiated by addition of the sample (supernatant of the gill or liver) to the reactive mixture (K phosphate buffer $0.1 \mathrm{M} ; \mathrm{pH}$ 7.6; $2 \mathrm{mM} \mathrm{NADPH}$, and $0.1 \mathrm{mM}$ 7-ethoxyresorun). The progressive increase in fluorescence resulting from the formation of resorun was measured every minute, up to 10 minutes for liver and 20 minutes for gill (excitation: $530 \mathrm{~nm}$ and emission: $590 \mathrm{~nm}$ ). The initial linear portion of the curve was used to assess the rate of reaction and the EROD activity was expressed as pmol resorun $\mathrm{min}^{-1} \mathrm{mg}$ protein ${ }^{-1}$, based on a standard curve of resorun. GST activity was determined following the complexation of GSH with 1-chloro-2,4dinitrobenzene (CDNB), at $340 \mathrm{~nm}$ (Keen et al., 1976), expressed as nmol of conjugated CDNB min $^{-1} \mathrm{mg}_{\text {protein }}{ }^{-1}$.

The SOD activity was determined by measuring the inhibition of the reduction rate of cytochrome $\mathrm{c}$ by $\mathrm{O}_{2}^{-*}$ derived from the xanthine/xanthine oxidase system at $550 \mathrm{~nm}$ according to McCord \& Fridovich (1969). The activity of this enzyme was expressed as U SOD mg protein ${ }^{-1}$. One unit (U) of SOD represents the amount of enzyme required to produce $50 \%$ inhibition of the reduction rate of cytochrome $\mathrm{c}$. Catalase activity was determined by following the rate of decomposition of $\mathrm{H}_{2} \mathrm{O}_{2}$ by the decrease in absorbance at $240 \mathrm{~nm}$ (Beutler, 1975). The enzyme activity was expressed in $\mu \mathrm{mol} \mathrm{H}_{2} \mathrm{O}_{2} \mathrm{~min}^{-1} \mathrm{mg}$ protein${ }^{1}$. The activity of selenium-dependent GPx was determined by the method of Hopkins \& Tudhope (1973), based on oxidation of $\mathrm{NADPH}+\mathrm{H}^{+}$in the presence of $\mathrm{H}_{2} \mathrm{O}_{2}$ at $340 \mathrm{~nm}$. The enzyme activity was expressed as mmol oxidized NADPH $\mathrm{min}^{-1} \mathrm{mg}$ protein $^{-1}$. The GR was determined indirectly by the reduction of NADPH in presence of oxidized glutathione (GSSG) (Carlberg \& Mannervik, 1975) at $340 \mathrm{~nm}$. The enzyme activity was expressed as $\mu$ mol oxidized NADPH min $^{-1} \mathrm{mg}_{\text {protein }}^{-1}$.

The concentration of GSH was determined according to the method of Beutler et al. (1963). Trichloroacetic acid (TCA) $(1: 1 \mathrm{v} / \mathrm{v}$ TCA $6 \%)$ was added to the samples. After centrifugation $(1,200 \mathrm{~g}), \mathrm{K}$ phosphate buffer $0.1 \mathrm{M}$, pH 7.0 and 2.5 mM DTNB (5.5-ditiobis-2-nitrobenzoic acid) was added to form the thiolate anion, determined at $412 \mathrm{~nm}$. The GSH content was expressed as $\mu \mathrm{g}$ of GSH mg of protein $^{-1}$ from a standard curve from 10 to $200 \mu \mathrm{M}$ of GSH.

Lipid peroxidation was estimated by quantification of malondialdehyde (MDA), which corresponds to one of the end products of LPO, by TBARS assay, following the methodology of Camejo et al. (1998). In summary, the determination of MDA was quantified by reaction with thiobarbituric acid (TBA) at $530 \mathrm{~nm}$. The LPO was expressed in MDA equivalents, as $\mu \mathrm{mol}$ MDA mg protein ${ }^{-1}$, using a standard curve of MDA.

AChE activity was determined based on the colorimetric method of Ellman et al. (1961) adapted for microplate reading, according to Alves-Costa et al. (2007). The enzyme activity was determined by quantifying the reaction product of acetylcholine with DTNB, at $415 \mathrm{~nm}$. The enzyme activity was expressed as nmol DTNB min $^{-1} \mathrm{mg}$ protein ${ }^{-1}$.

Protein concentration was determined according to the method of Lowry et al. (1951) using bovine serum albumin as standard and, the absorbance was determined on a spectrophotometer at $700 \mathrm{~nm}$. The data of protein concentrations were used to express the results of all data previously obtained.

\section{Analysis of DNA damage - Comet assay}

The comet assay was performed using the alkaline $(\mathrm{pH}>13)$ version developed by Singh et al. (1988), with the modifications detailed by Cavalcante et al. (2008), using two cell types: erythrocytes and gill cells. For gills dissociation firstly the organ was cleaned with phosphate buffered saline (PBS: $126.6 \mathrm{mM}$ $\mathrm{NaCl}, 4.8 \mathrm{mM} \mathrm{KCL}, 1.5 \mathrm{mM} \mathrm{CaCl}, 3.7 \mathrm{mM} \mathrm{NaHCO}, 8.9 \mathrm{mM}$ $\mathrm{Na}_{2} \mathrm{HPO}_{4}, 2.9 \mathrm{mM} \mathrm{NaH}_{2} \mathrm{PO}_{4}$ ), gill filaments were sectioned and the pieces were transferred to microtubes, incubated for $15 \mathrm{~min}$ at $30^{\circ} \mathrm{C}$ in $0.05 \%$ trypsin (diluted in $\mathrm{PBS} \mathrm{Ca}^{+2}$ and $\mathrm{Mg}^{+2}$ free) and homogenized by periodic manual inversion at room temperature. After that, the solution was filtered ( $30 \mu \mathrm{m}$ mesh size) into a tube containing a fetal calf serum $10 \%$ to halt the enzymatic digestion. The resultant solution was centrifuged $(10 \mathrm{~min}, 1,000 \mathrm{~g}$ ) and the pellet was resuspended in PBS to be used in the comet assay. Only blood and gill cells samples with cellular viability greater than $80 \%$, determined by the Trypan blue exclusion test, were used in the assay.

Basic steps of the comet assay for the two cell types were executed as follows: a) lysis: one hour, at $4^{\circ} \mathrm{C}$, protected from light, in a lysis buffer $(2.5 \mathrm{MNaCl}, 100 \mathrm{mM}$ EDTA, $10 \mathrm{mM}$ Tris, $10 \%$ DMSO, 1 mL Triton X-100, pH 10.0); b) DNA unwinding: $30 \mathrm{~min}$, in the dark, in an electrophoresis buffer $(0.3 \mathrm{~N} \mathrm{NaOH}, 1$ mM EDTA, $\mathrm{pH}>13$ ); c) electrophoresis: $20 \mathrm{~min}, 300 \mathrm{~mA}, 25 \mathrm{~V}$, 1 V.cm-1; d) neutralization: three washes for 5 min each in buffer (0.4 M Tris, $\mathrm{pH}$ 7.5). Slides were fixed with absolute ethanol for $10 \mathrm{~min}$ and kept under refrigeration until cytological analyses.

The slides were stained with gelRed (Biotium) and analyzed under Leica fluorescence microscopy with a blue excitation filter $(450-490 \mathrm{~nm})$ and a barrier filter of $515 \mathrm{~nm}$ at $1000 \mathrm{x}$ 
magnification. All slides were independently coded and blindly scored. The extent of DNA damage was quantified by the length of DNA migration, which was visually determined in 100 randomly select and non-overlapping cells per fish. According to Kobayashi et al. (1995), DNA damage was classified in four classes (0: no visible damage; 1 : a short tail smaller than the diameter of the nucleus; 2 : a tail length one to two times the diameter of the nucleus; 3 : a tail length $>$ two times the diameter of the nucleus). The score of DNA damage for 100 comets was obtained by multiplying the number of cells in each class by the damage class, and ranged from 0 (all undamaged) to 300 (all maximally damaged). Results for DNA damage in each cell type were expressed as the mean score of DNA damage for each treatment group, for each exposure period.

\section{Statistical analysis}

Considering that the toxicity tests for each concentration of lyophilized MA ( 1 or $2 \mathrm{mg} \mathrm{L}^{-1}$ ) and each exposure period (24 and $96 \mathrm{~h}$ ) were run independently, the results of the control and respective treated group, for each concentration of MA and each exposure period ( 24 and $96 \mathrm{~h}$ ), were compared using Student's t test or nonparametric Mann-Whitney test, depending on data distribution (normality and homogeneity of variances). Values were considered significant at $\mathrm{p}<0.05$.

\section{Results}

During the experiments, the water parameters remained constant, with the following values being found in the control group and treated groups (mean $\pm \mathrm{SEM}$ ), respectively: temperature $\left(21.79 \pm 1.43\right.$ and $\left.21.54 \pm 1.96^{\circ} \mathrm{C}\right), \mathrm{pH}(7.24 \pm 0.22$ and $7.04 \pm 0.33)$, conductivity $(97.17 \pm 7.82$ and $94.33 \pm 4.67 \mu \mathrm{S}$ $\left.\mathrm{cm}^{-1}\right)$ and dissolved oxygen $\left(8.32 \pm 0.43\right.$ and $7.86 \pm 0.20 \mathrm{mgO}_{2}$ $\left.\mathrm{L}^{-1}\right)$. The concentration of MC-LR in the water of treated groups containing 1 or $2 \mathrm{mg} \mathrm{L}^{-1}$ of lyophilized MA was 0.9 and $1.9 \mu \mathrm{g} \mathrm{L}^{-1}$ of MC-LR, respectively.

EROD activity in gills of fish exposed to both concentrations of lyophilized MA at the two experimental times did not show any significant difference in relation to respective controls (Fig. 1a). On the other hand, the animals exposed to $2 \mathrm{mg} \mathrm{L}^{-1}$ of lyophilized MA for $96 \mathrm{~h}$ showed a significant increase in the activity of EROD, in liver, when compared to their respective control (Fig. 1b).

Fish exposed to $2 \mathrm{mg} \mathrm{L}^{-1}$ of lyophilized MA for $24 \mathrm{~h}$ and 96 $\mathrm{h}$ showed a significant increase in the gill GST when compared to their respective controls (Fig. 2a). Liver GST activity increased significantly only in fish exposed for $24 \mathrm{~h}$ to lower concentration of lyophilized MA (Fig. 2b).

The SOD activity in gills of fish exposed to both concentrations of lyophilized MA were not significantly different, compared to respective control groups, regardless of the exposure time (Fig. 3a). After $24 \mathrm{~h}$ of exposure to $1 \mathrm{mg}$ $\mathrm{L}^{-1}$ lyophilized MA the animals showed a significant increase in gill activity of CAT and GPx compared to respective controls (Figs. 3b and 3c). In addition, the gill GPx, also, significantly increased after $96 \mathrm{~h}$ exposure to $2 \mathrm{mg} \mathrm{L}^{-1}$ of

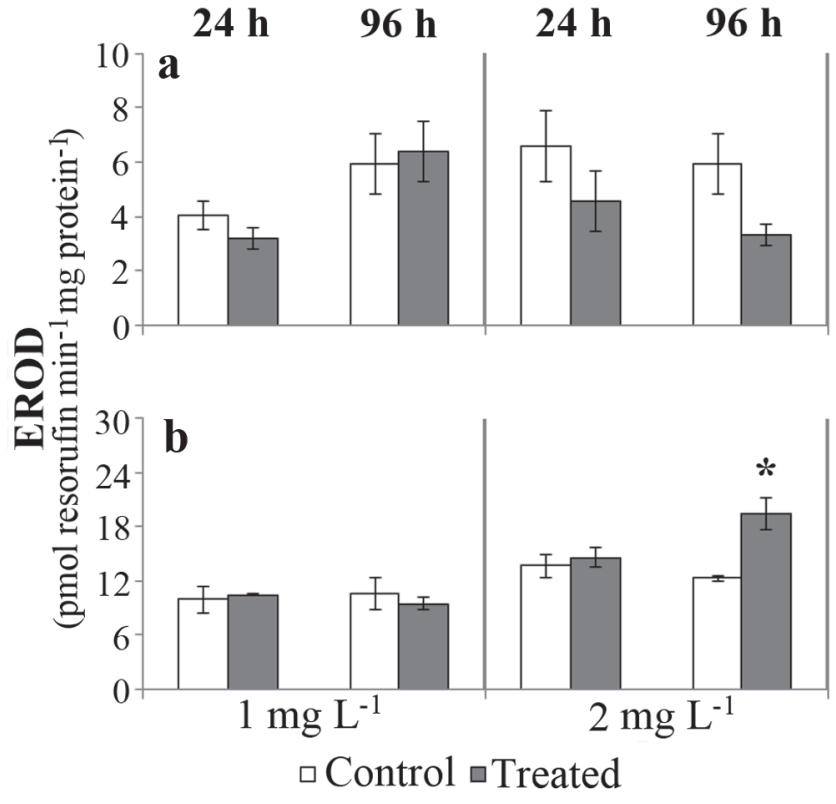

Fig. 1. Etoxiresorufina-O-desetilase (EROD) activity in gills (a) and liver (b) of Prochilodus lineatus exposed to 1 or $2 \mathrm{mg}$ $\mathrm{L}^{-1}$ lyophilized Microcystis aeruginosa (treated) or only water (control), for 24 and $96 \mathrm{~h}$. Values are presented as mean \pm SEM $(n=8)$. Asterisk indicates significant difference when compared to respective control $(\mathrm{p}<0.05)$.

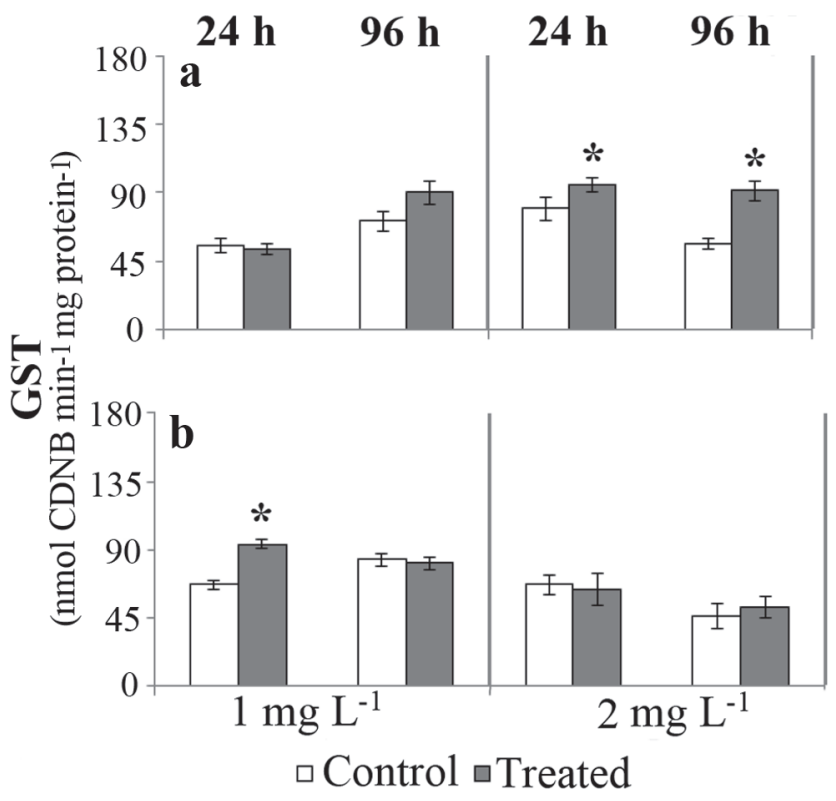

Fig. 2. Activity of glutathione S-transferase (GST) in gills (a) and liver (b) of Prochilodus lineatus exposed to 1 or $2 \mathrm{mg} \mathrm{L}^{-}$ ${ }^{1}$ lyophilized Microcystis aeruginosa (treated) or only water (control), for 24 and $96 \mathrm{~h}$. Values are presented as mean \pm $\operatorname{SEM}(\mathrm{n}=8)$. Asterisks indicate significant differences when compared to respective control $(\mathrm{p}<0.05)$. 
lyophilized MA. In relation to GR, was observed a significant increase in gill activity after $96 \mathrm{~h}$ of exposure to both concentrations of lyophilized MA, in relation to their respective controls (Fig. 3d).

After $96 \mathrm{~h}$ exposure to $2 \mathrm{mg} \mathrm{L}^{-1}$ lyophilized MA, the hepatic activity of SOD increased significantly in relation to its respective control (Fig. 4a). On the other hand, the hepatic activity of CAT decreased significantly after $96 \mathrm{~h}$ exposure to both concentrations of lyophilized MA in comparison to their respective controls (Fig. 4b). The activity of GPx and GR in liver did not vary significantly after fish exposure to lyophilized MA (Figs. 4c-4d).

In the gills of fish exposed to $1 \mathrm{mg} \mathrm{L}^{-1}$ lyophilized MA for 96 $\mathrm{h}$ the GSH content decreased significantly in relation to its respective control (Fig. 5a). In the liver a significant increase of GSH content was observed after $24 \mathrm{~h}$ of exposure to $1 \mathrm{mg} \mathrm{L}^{-1}$ lyophilized MA and a significant decrease after $96 \mathrm{~h}$ exposure to $2 \mathrm{mg} \mathrm{L}^{-1}$ lyophilized MA (Fig. 5b).

The occurrence of LPO (in $\mu \mathrm{mol}$ MDA mg protein ${ }^{-1}$ ) in control groups ranged between (mean \pm SEM) $0.61 \pm 0.07$ and $0.84 \pm 0.14$ in the gills, and between $0.63 \pm 0.04$ and $0.82 \pm 0.10$ in the liver. No significant differences were observed in gills and liver of fish exposed to different concentrations of lyophilized MA, at both exposure times, in comparison to respective control groups.
Brain and muscle AChE activities of fish exposed to both concentrations of lyophilized MA did not show significant difference in comparison to respective control groups at any exposure time. AChE activity (in nmol DNTB $\mathrm{min}^{-1} \mathrm{mg}$ protein $^{-1}$ ) in control groups ranged between (mean \pm SEM) $28.35 \pm 1.88$ and $41.39 \pm 2.25$ in brain, and between $76.44 \pm$ 8.85 and $145.21 \pm 21.12$ in muscle.

The comet assay showed that only the erythrocytes of fish exposed to $1 \mathrm{mg} \mathrm{L}^{-1}$ lyophilized MA for $96 \mathrm{~h}$ showed a comet score significantly higher than its respective group control (Fig. 6).

\section{Discussion}

The results obtained after exposure of Prochilodus lineatus to different concentrations of lyophilized MA containing MC-LR, at different times of exposure, support the idea that the MC-LR present in this material was able to promote the activation of biotransformation pathways, triggered different responses in antioxidant defenses and produced DNA damage. Some of these effects were found after exposure to lyophilized MA containing $0.9 \mu \mathrm{g} \mathrm{L}^{-1} \mathrm{MC}$ LR, this concentration is very close to the maximum concentration $\left(1 \mu \mathrm{g} \mathrm{L}^{-1}\right)$ established by the World Health Organization (WHO, 1998) for drinking water.

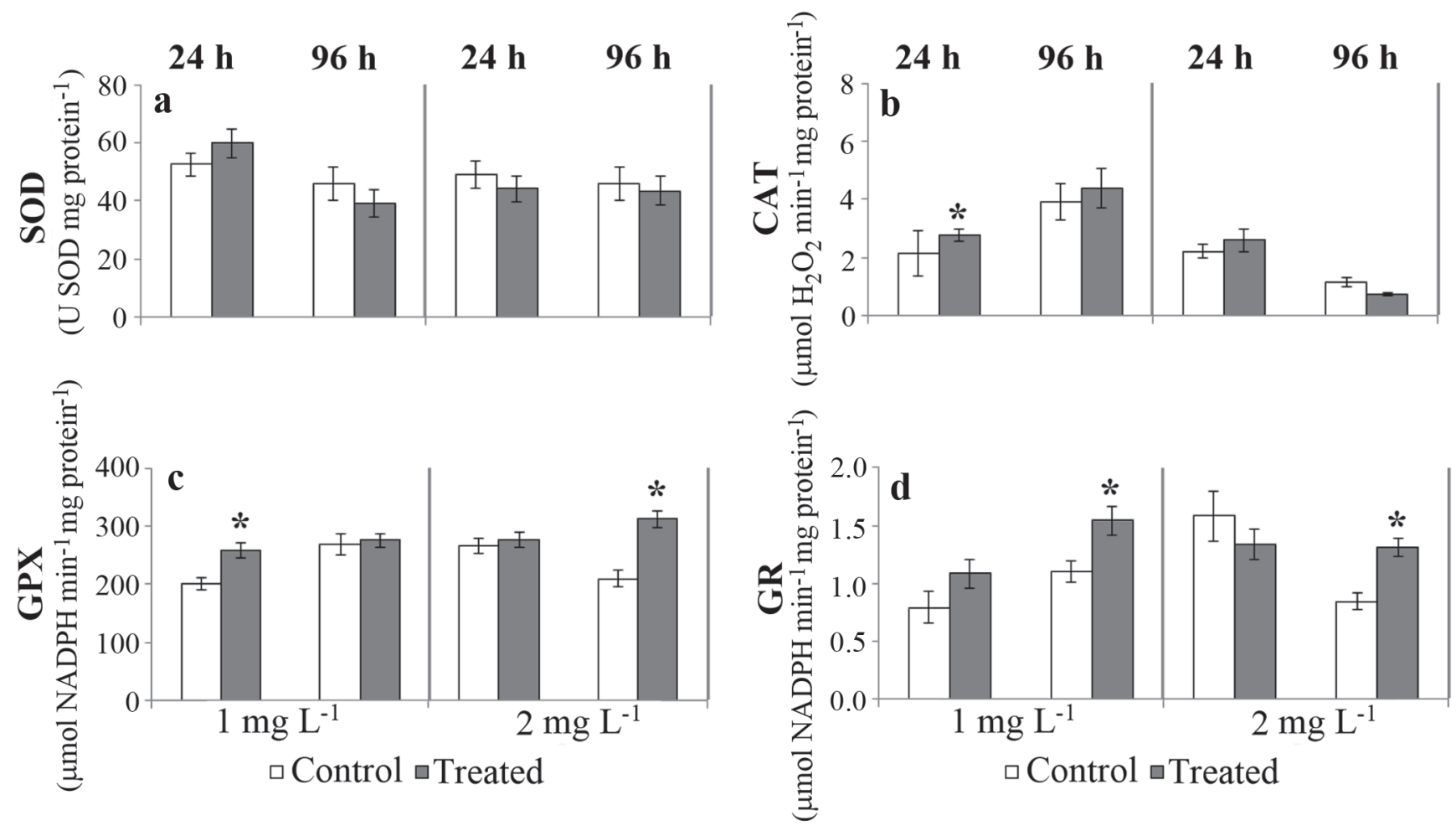

Fig. 3. Activity of superoxide dismutase (SOD; a), catalase (CAT; b), glutathione peroxidase (GPx; c) and glutathione reductase (GR; d) in gills of Prochilodus lineatus exposed to 1 or $2 \mathrm{mg} \mathrm{L}^{-1}$ lyophilized Microcystis aeruginosa (treated) or only water (control), for 24 and $96 \mathrm{~h}$. Values are presented as mean \pm SEM $(n=8)$. Asterisks indicate significant differences when compared to respective control $(\mathrm{p}<0.05)$. 

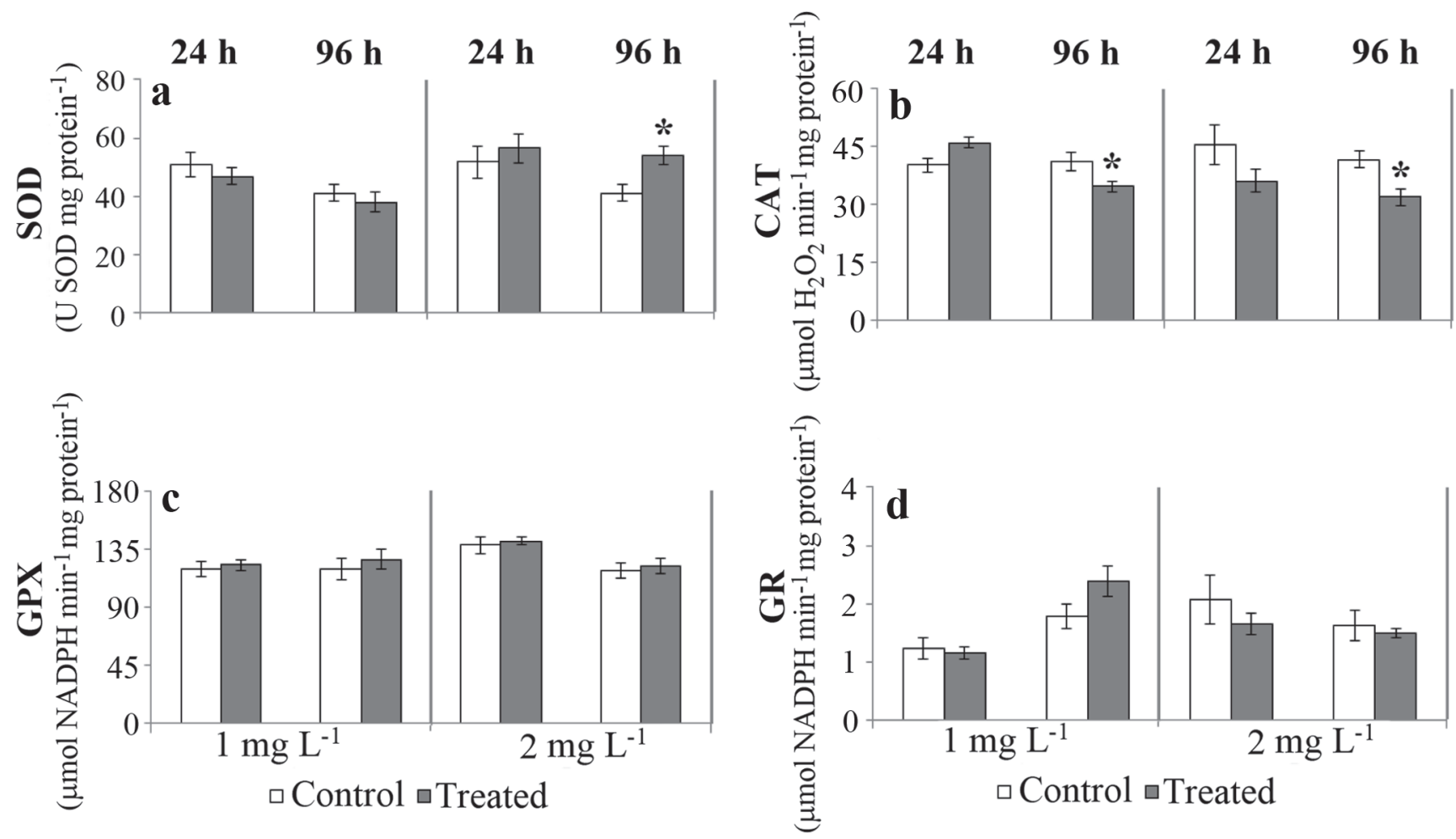

Fig. 4. Activity of superoxide dismutase (SOD; a), catalase (CAT; b), glutathione peroxidase (GPx; c) and glutathione reductase (GR; d) in liver of Prochilodus lineatus exposed to 1 or $2 \mathrm{mg} \mathrm{L}^{-1}$ lyophilized Microcystis aeruginosa (treated) or only water (control), for 24 and $96 \mathrm{~h}$. Values are presented as mean \pm SEM $(n=8)$. Asterisks indicate significant differences when compared to respective control $(\mathrm{p}<0.05)$.

Once absorbed, the MCs are distributed in various organs where they can be biotransformed. In this process, lipophilic compounds are converted to less toxic hydrophilic compounds, so that they can be more easily eliminated (Van der Oost et al., 2003; Cazenave et al., 2006). This process of detoxification can occur in two phases, with phase I mediated by enzymes of the cytochrome P450 family and in fish, the main enzyme involved in this process is the CYP1A subfamily, and in phase II, the most important enzyme is the GST. Although activation of CYP1A, quantified by means of EROD, was found in liver of $P$. lineatus at the longer exposure to the higher concentration, this is not a phenomenon often observed after exposure to different types of MCs. Wang et al. (2006) after exposure (i.p.) of tilapia, Oreochromis niloticus, to MC-LR did not observe any change in the level of CYP1A, quantified by the mRNA expression of cytochrome P450 1A.

Previous studies have already demonstrated that the process of detoxification of MC occurs mainly through conjugation with GSH via GST. Kondo et al. (1996) demonstrated that the conversion of MC in a more polar compound, usually occurring in liver, is correlated with the depletion of the pool of glutathione (GSH), which is a cofactor for the enzyme activity of GST. Pflugmacher et al. (1998) were the first to describe the formation of an MC-GSH conjugate in a reaction catalysed by GST, which is considered the primary route of detoxification of toxic cyanobacteria. In fact, the combination of MC with GSH via GST decreases the occurrence of tissue damage (Ding et al., 2000) and prevents the xenobiotic contact with other organs, or even the reaction with other substances, thereby protecting the organism from the occurrence of toxic effects generated by MC (Pinho et al., 2005). In the present study, GST activity increased both in the gills and liver, demonstrating the capacity for detoxification of the exposed fish to MC. According to the literature, the organ most associated with the processes of biotransformation is the liver (Van der Oost et al., 2003), but some authors have suggested other organs as detoxified, especially the gills, kidney and intestine (Jönsson et al., 2009). In the present study we observed that for $P$. lineatus besides the liver also the gills represent an organ that detoxifies MC.

Several studies have demonstrated that MC induces the production of ROS (Ding et al., 2001; Li et al., 2003; Weng et al., 2007; Atencio et al., 2008) that must be counteracted by the antioxidant defense of the animal and SOD, CAT, GPx and GR are part of this system (Van der Oost et al., 2003; Cazenave et al., 2006). SOD and CAT are primary antioxidant enzymes and the simultaneous induction of these enzymes is normally observed after the exposure to contaminants (Pandey et al., 2003; Atencio, 2008); however in the present work the responses of these two enzymes in both tissues were quite 


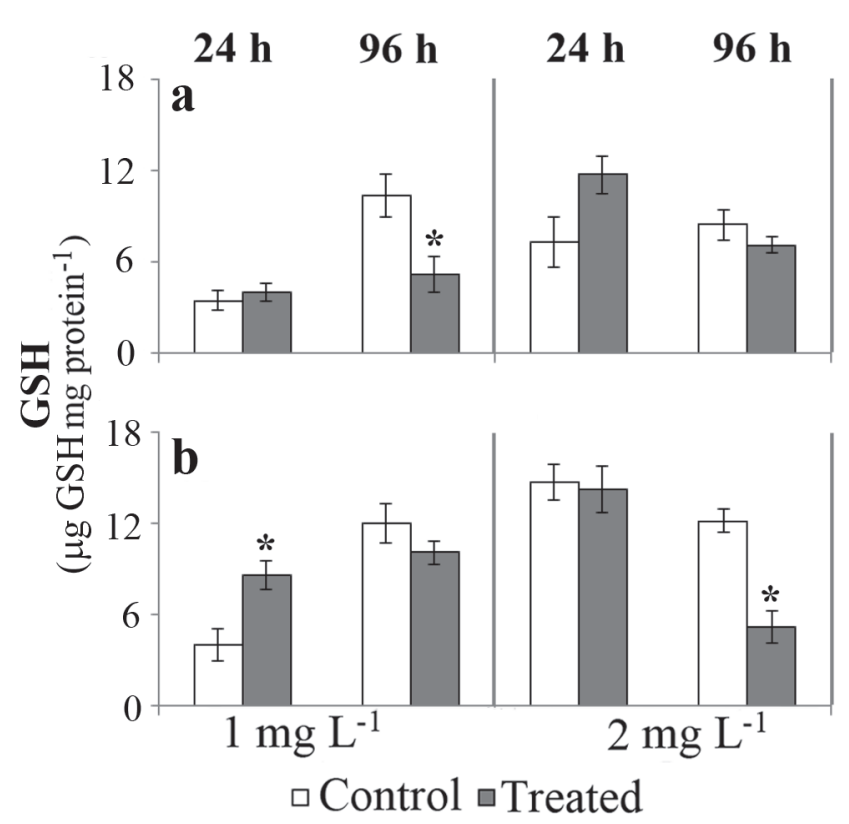

Fig. 5. Content of reduced glutathione (GSH) in gills (a) and liver (b) of Prochilodus lineatus exposed to 1 or $2 \mathrm{mg} \mathrm{L}^{-1}$ lyophilized Microcystis aeruginosa (treated) or only water (control), for 24 and $96 \mathrm{~h}$. Values are presented as mean \pm $\operatorname{SEM}(n=8)$. Asterisks indicate significant differences when compared to respective control $(\mathrm{p}<0.05)$.

varied: induction of gill CAT after $24 \mathrm{~h}$ of exposure to $1 \mathrm{mg} \mathrm{L}$ ${ }^{1}$ lyophilized MA and inhibition of hepatic CAT after $96 \mathrm{~h}$ of exposure to both concentrations of MA. This branchial CAT induction suggests an increase in the concentration of $\mathrm{H}_{2} \mathrm{O}_{2}$ due to the high specificity of this enzyme to detoxify this ROS. Ding et al. (2001) showed that after exposure of primary cultured hepatocytes to MC-LR, an increase of $\mathrm{H}_{2} \mathrm{O}_{2}$ occurs, leading to damage to the cell cytoskeleton and, subsequently, apoptosis. Despite the increase in branchial CAT it should be kept in mind that the $P$. lineatus gills contain much smaller amounts of this enzyme than the liver (Simonato et al., 2011). However, as ROS can activate enzyme activity, they can also initiate enzyme inhibition, and this process can be promoted both by the excess of oxidant or by the excess of its own substrate. SOD, for example, can be inhibited by an excess of $\mathrm{H}_{2} \mathrm{O}_{2}$, and CAT by $\mathrm{O}_{2}^{-\bullet}$ (Pandey et al., 2003). As after exposure to $1 \mathrm{mg} \mathrm{L}^{-1}$ lyophilized MA at $96 \mathrm{~h}$ there was no activation of SOD, it can be inferred that the liver CAT was inhibited due to an excess of $\mathrm{O}_{2}^{-*}$. However, after exposure to $2 \mathrm{mg} \mathrm{L}^{-1}$ lyophilized MA for the same experimental time this argument is not valid, since liver SOD activity was significantly increased. However, previous studies have shown that $\mathrm{O}_{2}^{-}$ is not the only one capable of promoting the inactivation of CAT, but also singlet oxygen and peroxyl radicals (Pinho et al., 2005). Therefore, we can suggest that these two other reactive species may have been responsible for the inhibition

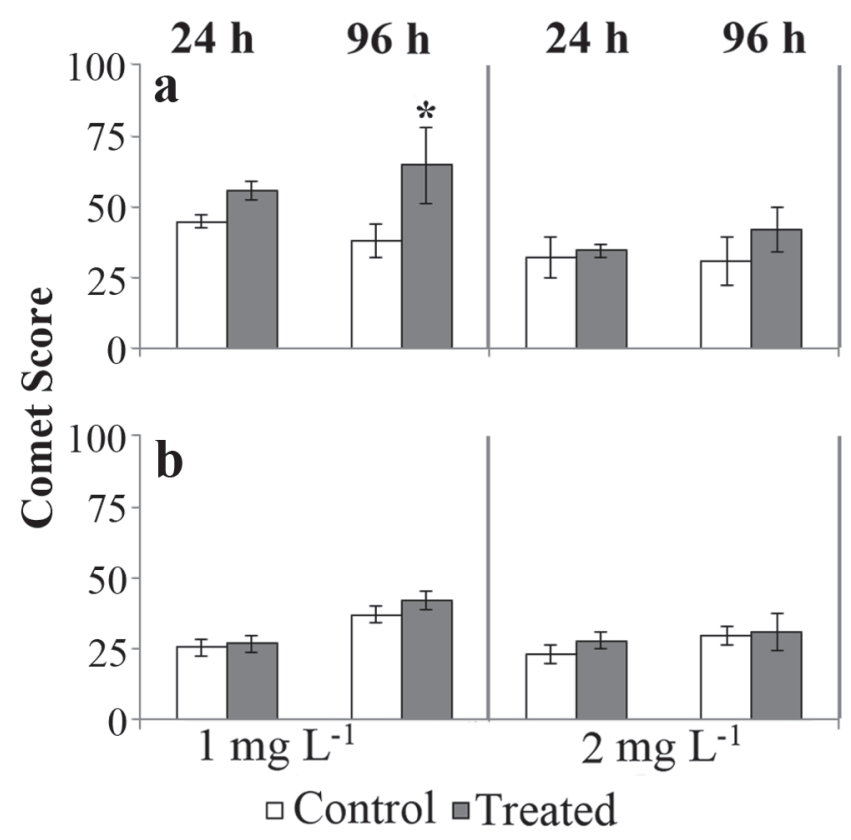

Fig. 6. Comet scores of DNA damage in erythrocytes (a) and branchial cells (b) of Prochilodus lineatus exposed to 1 or 2 $\mathrm{mg} \mathrm{L}^{-1}$ lyophilized Microcystis aeruginosa (treated) or only water (control), for 24 and $96 \mathrm{~h}$. Values are presented as mean \pm SEM $(n=4-8)$. Asterisks indicate significant differences when compared to respective control $(\mathrm{p}<0.05)$.

of CAT after $96 \mathrm{~h}$ exposure to higher concentration of MA.

In this work an increase in GPx activity was observed only in the gills, while no significant change was observed in the liver, contradicting some studies that showed a significant increase of hepatic GPx after microcystin exposure. Jos et al. (2005) and Cazenave et al. (2006) found a significant increase of GPx in liver of Oreochromis sp. after 21 days exposure to MC-LR and in liver of Corydoras paleatus after $24 \mathrm{~h}$ exposure to MC-RR, respectively. An increase in GPx activity was also found in Cyprinus carpio hepatocytes after in vitro exposure to MC-LR (Li et al., 2003) and in liver of Misgurnus mizolepis after oral exposure to MC-RR (Li et al., 2005). However, this increase in GPx after exposure to different types of MC is not a rule. In other study (Prieto et al., 2006) no significant changes in GPx activities were observed in gill or liver after i.p. injection of MC-LR and MC-RR in Oreochromis sp. These differences in the response of GPx may be due to different types of experimental systems, exposure times, routes, and concentrations or doses employed in the studies (Prieto et al., 2006). The increase in GPx activity in gills reinforces the idea of an increase in the concentration of $\mathrm{H}_{2} \mathrm{O}_{2}$ in this organ, probably caused by exposure to MC. And, although there was an increase in gill CAT, the activity of this enzyme in this organ is not very representative for the animal. Thus, we can infer that in P. lineatus the gill GPx is acting with greater intensity in the elimination of reactive species than the CAT. 
The GR has an important role as an antioxidant within the cell, since it is responsible for catalysing the reduction of GSSG to its reduced form, GSH, necessary for cell protection against oxidative stress (Tekman et al., 2008). Fish from polluted sites can show increased GR activity because of the high concentration of peroxidative components present in aquatic environments (Stephensen et al., 2000). In the present study an increase in GR activity was observed only in the gills after exposure to $96 \mathrm{~h}$ to both concentrations of lyophilised MA. Jos et al. (2005) also observed a significant increase in liver and kidney GR of Oreochromis sp. exposed to MC-LR.

Although the concentration of hepatic GSH may be regarded as a good biomarker for exposure to MC (Atencio et al., 2008), some studies have shown a fairly sharp change in its level after exposure of fish and other aquatic organisms to this cyanotoxin. The significant increase of this tripeptide was observed in the hepatopancreas of Cyprinus carpio after exposure to MC-LR (Li et al., 2003); its decrease was observed in Hypophthalmichthys molitrix after exposure to a bloom of cyanobacteria (Bláha et al., 2004) and no difference was observed in Tinca tinca orally exposed to MC-LR (Atencio et al., 2008). In the present work it was observed a significant increase in liver GSH after $24 \mathrm{~h}$ of exposure to lyophilized MA, and a significant decrease in liver and gills after $96 \mathrm{~h}$ of exposure to lyophilized MA. This significant increase after $24 \mathrm{~h}$ exposure is probably due to the increase in its synthesis since no significant increase was observed in the liver of GR.

The use of LPO as a biomarker of effect after exposure to $\mathrm{MC}$ has been widely used. In this study no significant changes were observed in the occurrence of LPO in gills and liver of $P$. lineatus after the exposure to lyophilized MA. The results observed for the gills of $P$. lineatus showed a significant increase in the activity of enzymatic antioxidants such as CAT, GPx, and GR and it can be suggested that the increase in antioxidant capacity due to the rise in these enzymes may have been sufficient to protect the animal from injury in the gills, since no increase in LPO was detected. In the liver, an increase in SOD activity $\left(96 \mathrm{~h} / 2 \mathrm{mg} \mathrm{L}^{-1}\right)$ and GSH content $(24$ $\mathrm{h} / 1 \mathrm{mg} \mathrm{L}^{-1}$ ) was observed without increase in LPO levels, which corroborates studies of Li et al. (2005) who also found an increase in antioxidant defenses and no change in the levels of LPO in liver of Misgurnus mizolepis orally exposed to MC-RR.

The comet assay has been increasingly used due to its simplicity, versatility, requirement of only a small number of cells per sample, relatively low cost and high sensitivity to various types of DNA damage (Olive \& Banath, 2006). In this study, the comet assay showed that the lyophilized MA was able to promote changes in the DNA molecule of erythrocytes of $P$. lineatus after $96 \mathrm{~h}$ exposure to $1 \mathrm{mg} \mathrm{L}^{-1}$ of lyophilized MA. These results give evidence that can be $\mathrm{MC}$ genotoxic to $P$. lineatus. Some other studies have already shown that $\mathrm{MC}$ promotes damage in the DNA molecule (Zegura et al., 2003) and that DNA damage is promoted by ROS and not by a direct interaction of MC with the DNA molecule (Zegura et al., 2004).
In this study, AChE activity did not show any changes from its basal level in the brain and muscle of $P$. lineatus after exposure to lyophilised MA, containing MC-LR. According to the current knowledge, the effects of $\mathrm{MC}$ are not directly associated with the activity of AChE. Among the cyanotoxins, the ones that have the greatest influence on AChE activity are the group of neurotoxins, such as anatoxins, which act by inhibiting the activity of AChE (Monserrat et al., 2001).

Given the findings of this study it can be conclude that the exposure of $P$. lineatus to lyophilised MA was able to promote the activation of biotransformation, as demonstrated by the increase in liver and gills GST activity, and changes in the antioxidant defense of both tissues. The gills showed larger antioxidant responses when compared with the liver but LPO was not detected in both tissues. Comet assay results showed that the exposure to lyophilised MA, containing MC$\mathrm{LR}$, was able to induce DNA damage in fish erythrocytes.

\section{Acknowledgements}

The authors thank the Hatchery Station of the State University of Londrina for supplying the fish and Alessandro Minillo for the donation of lyophilised MA. This work is part of the Master thesis of C. Z. Garcia who received a scholarship from the Conselho Nacional de Desenvolvimento Científico e Tecnológico (CNPq). C. B. R. Martinez is research fellow from $\mathrm{CNPq}$ and member of the Brazilian Institute of Aquatic Toxicology (INCT-TA, CNPq number: 573949/2008-5).

\section{Literature Cited}

Alves Costa, J. R. M., M. Mela, H. C. Silvia de Assis, E. Pelletier, M. F. Randi \& C. A. Oliveira Ribeiro. 2007. Enzymatic inhibition and morphological changes in Hoplias malabaricus from dietary exposure to lead (II) or methylmercury. Ecotoxicology and Environmental Safety, 67: 82-88.

Amado, L. L. \& J. M. Monserrat. 2010. Oxidative stress generation by microcystins in aquatic animals: Why and how. Environment International, 36: 226-235.

Antoniou, M. G., J. A. Shoemaker, A. A. Cruz \& D. D. Dionysiou. 2008. LC/MS/MS structure elucidation of reaction intermediates formed during the $\mathrm{TiO}_{2}$ photocatalysis of microcystin-LR. Toxicon, 51: 1103-1118.

Atencio, L., I. Moreno, A. Jos, S. Pichardo, R. Moyano, A. Blanco \& A. M. Cameán. 2008. Dose-dependent antioxidant responses and pathological changes in tenca (Tinca tinca) after acute oral exposure to Microcystis under laboratory conditions. Toxicon, 52: $1-12$.

Beutler, E., O. Durom \& B. M. Kelly. 1963. Improved method for the determination of blood glutathione. The Journal of laboratory and clinical medicine, 61: 882-890.

Beutler, E. 1975. Red Cell Metabolism: A manual of biochemical methods. New York: Grune and Straton.

Bláha, L., R. Kopp, K. Imková \& J. Mares. 2004. Oxidative stress biomarkers are modulated in silver carp (Hypophthalmichthys molitrix Val.) exposed to microcystin-producing cyanobacterial water bloom. Acta Veterinaria Brno, 73: 477-482.

Camejo, G., B. Wallin \& M. Enojärvi. 1998. Analyses of Oxidation and Antioxidants using Microtiter Plates. Pp. 377-387. In: 
Amstrong, D. (Ed.). Free radical and antioxidants protocols. Humana Press, New Jersey, 455p.

Campos, A. \& V. Vasconcelos. 2010. Molecular Mechanisms of Microcystin Toxicity in Animal Cells. International Journal of Molecular Science, 11:268-287.

Carlberg, I. \& B. Mannervik. 1975. Purification and characterization of the flavoenzyme glutathione reductase from rat liver. The Journal of Biological Chemistry, 260: 5475-5480.

Cavalcante, D. G. S. M., C. B. R. Martinez \& S. H. Sofia. 2008. Genotoxic effects of Roundup ${ }^{\circledR}$ on the fish Prochilodus lineatus. Mutation Research, 655: 41-46.

Cazenave, J., M. A. Bistoni, S. F. Pesce \& D. A. Wunderin. 2006. Differential detoxication and antioxidant response diverse organs of Corydoras paleatus experimentally exposed to microcystinRR. Aquatic Toxicology, 76: 1-12.

Chen, T., J. Cui, Y. Liang, X. Xin, D. O. Young, C. Chen \& P. Shen. 2006. Identification of liver mitochondrial aldehyde dehydrogenase as a potential target for microcystin-LR. Toxicology, 220: 71-80.

Ding, W. X., H. M. Shen \& C. N. Ong. 2000. Microcystic cyanobacteria extract induces cytoskeletal disruption and intracellular glutathione alteration in hepatocytes. Environmental Health Perspective, 108: 605-609.

Ding, W., H. Shen \& C. Ong. 2001. Critical role of ROS formation in microcystin-induced cytoskeletal disruption in primary cultured hepatocytes. Journal Toxicology Environmental Health, 64: 507-519.

Dutta, H. M. \& D. A. Arends. 2003. Effects of endosulfan on brain acetylcholinesterase activity in juvenile bluegill sunsh. Environmental Research, 91: 157-162.

Eggens, M. L. \& F. Galgani. 1992. Ethoxyresorufin- $O$-deethylase (EROD) activity in flatfish - fast determination with a fluorescence plate-reader. Marine Environmental Research, 33: 213-221.

Ellman, G. L., K. D. Courtney, V. Andres Jr. \& R. M. Featherstone. 1961. A new and rapid colorimetric determination of acetylcholinesterase activity. Biochemical Pharmacology, 7: 88-95.

Ferrari, A., A. Venturino \& A. M. Péchen de D’Angelo. 2007. Muscular and brain cholinesterase sensitivities to azinphos methyl and carbaryl in the juvenile rainbow trout Oncorhynchus mykiss. Comparative Biochemistry and Physiology, 146C: 308-313.

Fischer, W. J., S. Altheimer, V. Cattori, P. J. Meier, D. R. Dietrich \& B. Hagenbuch. 2005. Organic anion transporting polypeptides expressed in liver and brain mediate uptake of microcystin. Toxicology and Applied Pharmacology, 203: 257-263.

Hopkins, J. \& G. R. Tudhope. 1973. Glutathione peroxidase in human red cells in health and disease. Journal Haematology, 25: 563-575.

Jönsson, M. E., B. Brunström \& L. Brandt. 2009. The zebrafish gill model: Induction of CYP1A, EROD and PAH adduct formation. Aquatic Toxicology, 91: 62-70.

Jos, A., S. Pichardo, A. I. Prieto, G. Repetto, C. M. Vázquez, I. Moreno \& A. M. Cameán. 2005. Toxic cyanobacterial cells containing microcystins induce oxidative stress in exposed tilapia fish (Oreochromis sp.) under laboratory conditions. Aquatic Toxicology, 72: 261-271.

Keen, J. H., W. H. Habig \& W. B. Jakobi. 1976. Mechanism for the several activities of the glutathione-S-transferase. Journal of Biology Chemistry, 251: 6183-6188.

Kobayashi, H., C. Sugiyama, Y. Morikawa, M. Hayashi \& T. A. Sofuni. 1995. Comparison between manual microscopic analysis and computerized image analysis in the single cell gel electrophoresis. MMS Commun, 3: 103-115.

Kondo, F., H. Matsumoto, S. Yamada, N. Ishikawa, E. Ito, S. Nagata, Y. Ueno, M. Suzuki \& K. Harada. 1996. Detection and identication of metabolites of microcystins formed in vivo in mouse and rat livers. Chemical Research Toxicology, 9: 1355-1359.

Li, X., Y. Liu, L. Song \& J. Liu. 2003. Responses of antioxidant systems in the hepatocytes of common carp (Cyprinus carpio L.) to the toxicity of microcystin-LR. Toxicon, 42: 85-89.

Li, X., I. Chung, J. Kim \& J. Lee. 2004. Subchronic oral toxicity of microcystin in common carp (Cyprinus carpio L.) exposed to Microcystis under laboratory conditions. Toxicon, 44: 821-827.

Li, X. Y., I. K. Chung, J. I. Kim \& J. A. Lee. 2005. Oral exposure to Microcystis increases activity-augmented antioxidant enzymes in the liver of loach (Misgurnus mizolepis) and has no effect on lipid peroxidation. Comparative Biochemistry and Physiology, 141C: 292-296.

Livingstone, D. R. 2001. Contaminant-stimulated reactive oxygen species production and oxidative damage in aquatic organisms. Marine Pollution Bulletin, 42: 656-666.

Lowry, O. H., N. J. Rosebrough, A. L. Farr \& R. J. Randall. 1951. Protein measurements with the folin phenol reagent. The Journal of Biological Chemistry, 193: 265-275.

McCord, J. E. \& I. Fridovich. 1969. Superoxide dismutase. An enzymic function for erythrocuprein (hemocuprein). The Journal of Biological Chemistry, 244: 6049-6055.

Monserrat, J. M., J. S. Yunes \& A. Bianchini. 2001. Effects of Anabaena spiroides (cyanobacteria) aqueous extracts on the acetylcholinesterase activity of aquatic species. Environmental Toxicology and Chemistry, 20: 1228-1235.

Olive, P. L. \& J. P. Banath. 2006. The Comet assay: a method to measure DNA damage in individual cells. Nature Protocols, 1: 23-29.

Pandey, S., S. Parvez, I. Sayeed, R. Haque, B. Bin-Hafeez \& S. Raisuddin. 2003. Biomarkers of oxidative stress: a comparative study of river Yamuna fish Wallago attu (B1 and Schn.). The Science of the Total Environment, 309: 105-115.

Pasková, V., O. Adamovsky, J. Pikula, B. Skocovska, H. Band'Ouchova, J. Horáková, P. Babica, B. Marsálek \& K. Hilscherova. 2008. Detoxification and oxidative stress responses along with microcystins accumulation in Japanese quail exposed to cyanobacterial biomass. The Science of the Total Environment, 98: 34-47.

Pflugmacher, S., C. Wiegand, A. Oberemm, K. A. Beattie, E. Krause, G. A. Codd \& C. E. W. Steinberg. 1998. Identication of an enzymatically formed glutathione conjugate of the cyanobacterial hepatotoxin microcystin-LR. The first step of detoxication. Biochimica et Biophysica Acta, 1425: 527-533.

Pinho, G. L. L., C. Moura da Rosa, F. E. Maciel, A. Bianchini, J. S. Yunes, L. A. O. Proença \& J. M. Monserrat. 2005. Antioxidant responses and oxidative stress after microcystin exposure in the hepatopancreas of an estuarine crab species. Ecotoxicology and Environmental Safety, 61: 353-360.

Prieto, A. I., A. Jos, S. Pichardo, I. Moreno \& A. M. Cameán. 2006. Differential oxidative stress responses to microcystins LR and $\mathrm{RR}$ in intraperitoneally exposed tilapia fish (Oreochromis sp.). Aquatic Toxicology, 77: 314-321.

Singh, N. P., M. T. McCoy, R. R. Tice \& E. L. Schneider. 1988. A single technique for quantification of low levels of DNA damage in individual cells. Experimental Cell Research, 175: 184-191.

Simonato, J. D., M. N. Fernandes \& C. B. R. Martinez. 2011. Gasoline effects on biotransformation and antioxidant defenses 
of the freshwater fish Prochilodus lineatus. Ecotoxicology, 20: 1400-1410.

Stephensen, E., J. Svavarsson, J. Sturve, G. Ericson, M. AdolfssonErici \& L. Förlin. 2000. Biochemical indicators of pollution exposure in shorthorn sculpin (Myoxocephalus scorpius), caught in four harbours on the southwest coast of Iceland. Aquatic Toxicology, 48: 431-442.

Tekman, B., H. Ozdemir, M. Senturk \& M. Ciftci. 2008. Purication and characterization of glutathione reductase from rainbow trout (Oncorhynchus mykiss) liver and inhibition effects of metal ions on enzyme activity. Comparative Biochemistry and Physiology, 148C: 117-121.

Van der Oost, R., J. Beyer \& N. P. E. Vermeulen. 2003. Fish bioaccumulation and biomarkers in environmental risk assessment: a review. Environmental Toxicology and Pharmacology, 13: 57-149.

Wang, L., X. F. Liang, W. Q. Liao, L. M. Lei \& B. P. Han. 2006. Structural and functional characterization of microcystin detoxification-related liver genes in a phytoplanktivorous fish, Nile tilapia (Oreochromis niloticus). Comparative Biochemistry and Physiology, 144C: 216-227.
Weng, D., Y. Lu, Y. Wei, Y. Liu \& P. Shen. 2007. The role of ROS in microcystin-LR induced hepatocyte apoptosis and liver injury in mice. Toxicology, 232: 15-23.

WHO, 1998. Blue-green algae in inland waters: Assessment and control of risks to public health. World Health Organization (WHO) Document, Annex G.

Zegura, B., T. T. Lah \& C. M. Filipi. 2004. The role of reactive oxygen species in microcystin-LR-induced DNA damage. Toxicology, 200: 59-68.

Zegura, B., B. Sedmark \& M. Filipic. 2003. Microcystin-LR induces oxidative DNA damage in human hepatoma cell line HepG2. Toxicon, 41: 41-48.

Zimba, P. V., L. Khoo, P. Gaunt, W. W. Carmichael \& S. Brittaina. 2001. Conrmation of catfish mortality from Microcystis toxins. Journal of Fish Disease, 24: 41-47.

Submitted March 25, 2012

Accepted July 25, 2012

Published September 28, 2012 